11. Malpeli A, Ferrari MG, Varea A, Falivene M, et al. Shortterm evaluation of theimpact of a fortified food aid program on the micronutrient nutritional status of Argentinian pregnant women. Biol Trace Elem Res. 2013; 155(2):176-83.

12. Calvo E, Biglieri A. Impacto de la fortificación con ácido fólico sobre el estado nutricional en mujeres y la prevalencia de defectos del tubo neural. Arch Argent Pediatr. 2008; 106(6):492-8.

13. Bernztein R, Drake I. Subprescripción de hierro y variabilidad en el primer nivel de atención público de la Argentina. Arch Argent Pediatr. 2008; 106(4):320-7.

14. Ceriani Cernadas JM, Carroli G, Pellegrini L, Ferreira M, et al. Efecto del clampeo demorado del cordón umbilical en la ferritina sérica a los seis meses de vida: Estudio clínico controlado aleatorizado Arch Argent Pediatr. 2010; 108(3):201-8.
15. Marin GH, Mestorino N, Errecalde J, Huber B, et al. Personalised iron supply for prophylaxis and treatment of pregnant women as a way to ensure normal iron levels in their breast milk. J Med Life. 2012; 5(1):29-32.

16. WHO, UNICEF. Global Strategy on infant and young child feeding. 2012. [Accessed on: February 21 ${ }^{\text {st }}, 2020$ ]. Available at: https: / / www.who.int/nutrition/publications / infantfeeding/9241562218/en/

17. Neville MC, Anderson SM, McManaman JL, Badger TM, et al. Lactation and neonatal nutrition: defining the critical questions. J Mammary Gland Biol Neoplasia. 2012; 17(2):16788.

18. Mozaffarian D, Rosenberg I, Uauy R. History of modern nutrition science-implications for current research, dietary guidelines, and food policy. BMJ. 2018; 361:k2392.

\title{
Clinical and epidemiological study of acute lower respiratory tract infections caused by adenovirus in hospitalized children. Nineteen years of active epidemiological surveillance
}

Acute respiratory tract infections are the main cause of morbidity in the pediatric population. Although the burden of disease is higher in low-resource areas, those with greater resource availability face the challenge of antibiotic resistance in bacterial infections and the identification of new pathogens. ${ }^{1,2}$

In recent years, the identification of respiratory viruses and their role in pneumonia in the pediatric population have increasingly progressed. Molecular techniques used for viral diagnosis help to detect up to $92 \%$ of respiratory viruses in children with pneumonia. Viruses associated with community-acquired pneumonia include human adenovirus (HAdV), human bocavirus $(\mathrm{HBoV})$, human coronavirus $(\mathrm{HCoV})$, enterovirus (EV), influenza virus (Flu), human metapneumovirus (hMPV), parainfluenza virus (PIV), and respiratory syncytial virus (RSV). ${ }^{3,4}$

The case-control study conducted by Rhedin et al., in Stockholm analyzed the association between respiratory viruses and pneumonia in children younger than 5 years and detected viruses in $98 / 121$ children with pneumonia $(81 \%)$ and in $134 / 240$ controls $(56 \%)$. The univariate analysis showed that the viruses significantly associated with communityacquired pneumonia were hMPV $(p<0.001)$, RSV $(p<0.001)$, Flu $(p=0.03)$, and HAdV $(p=0.05)$, whereas in the multivariate analysis HAdV did not show a significant relation to pneumonia and was quite common among controls. ${ }^{3}$ This may be due to the fact that, although adenovirus causes community-acquired pneumonia, it has been observed that it may remain in the lymphatic tissue in the tonsils for weeks. On the other side, there have also been reports of adenovirus latency in the lungs and reactivation in immunosuppressed hosts. ${ }^{5}$

Nascimento-Carvalho et al., found viruses in 708 children younger than 5 years old with pneumonia $(91.5 \%$; $95 \%$ confidence interval [CI]: 89.3-93.3); of them, 491 (69.4 \%; $95 \%$ CI: 65.972.7) were identified as having a viral coinfection. Rhinovirus (46.1\%; 95 \% CI: 42.6-49.6), adenovirus (38.4\%; $95 \%$ CI: 35.0-41.8), and enterovirus (26.5\%; $95 \%$ CI: 23.5-29.7) were the most common viruses, and the most frequent co-infection corresponded to rhinovirus and adenovirus. ${ }^{4}$

Although adenovirus was the less commonly respiratory virus identified through the entire period in the study of Bakir et al., ${ }^{6}$ published in this issue of Archivos, $4.4 \%(265 / 6047)$ of all positive cases, this may be due to the lower sensitivity and specificity of indirect immunofluorescence (IIF). On the other side, having included children with bronchiolitis may also have contributed to the lower detection ratio. As mentioned in the article, the most common clinical presentation was pneumonia.

The study by Yu Lin et al., reported a higher 
frequency of respiratory viruses in the pediatric population by means of reverse transcription polymerase chain reaction (RT-PCR) $(75.3 \%)$ than with traditional testing techniques $(49.3 \%)$. The main pathogens detected were RSV $(23.8 \%)$, rhinovirus (15.2\%), PIV3 (11.2\%), FluA (10.8\%), and HAdV (10.1\%). RSV and rhinovirus were the most frequent pathogens among children younger than 5 years old, whereas FluA and HAdV, among those older than 5 years. ${ }^{7}$

On the other side in Bakir's study, ${ }^{6}$ it is worth nothing that among associated factors a high percentage of children with comorbilities was observed, possibly related to the characteristics of the institution. This may also be observed in relation to fatality, given that out of the 20 children who died, $55 \%$ had a comorbidity.

The following were identified as independent predictors of adenovirus infection: male sex, age 12 months or older, rehospitalization, prior hospitalization due to respiratory causes, and clinical presentation of pneumonia; this is relevant information in the case of suspicion of adenovirus.

In addition, considering that one of the predictors was pneumonia as an admission diagnosis, it is important to reinforce the significance of detecting respiratory viruses in lower respiratory tract infections to establish an adequate management and the need for isolation. As mentioned in Bakir's study, molecular biology techniques allow for a greater frequency of respiratory virus identification and the IIF is an appropriate screening technique.

It is important to continue with epidemiological surveillance and data analysis so as to identify any changes that may occur over time with the introduction of the pneumococcal vaccine and an adequate coverage. This way, an adequate antibiotic use and prevention measures to reduce nosocomial transmission can be facilitated.

Miriam Bruno, M.D. Health Promotion and Protection Division Hospital Carlos G. Durand Autonomus City of Buenos Aires

http:/ / dx.doi.org/10.5546/ aap.2020.eng.158

To cite: Bruno M. Clinical and epidemiological study of acute lower respiratory tract infections caused by adenovirus in hospitalized children. Nineteen years of active epidemiological surveillance [Commentary]. Arch Argent Pediatr 2020;118(3):158-159.

\section{REFERENCES}

1. Liu L, Oza S, Hogan D, Perin J, et al. Global, regional, and national causes of child mortality in 2000-13, with projections to inform post-2015 priorities: An updated systematic analysis. Lancet. 2015; 385(9966):430-40.

2. Walker CL, Rudan I, Liu L, Nair H, et al. Global burden of childhood pneumonia and diarrhoea. Lancet. 2013; 381(9875):1405-16.

3. Rhedin S, Lindstrand A, Hjelmgren A, Ryd-Rinder M, et al. Respiratory viruses associated with community-acquired pneumonia in children: matched case-control study. Thorax. 2015; 70(9):847-53.

4. Nascimento-Carvalho AC, Vilas-Boas AL, Fontoura MH, Vuorinen T, et al. Respiratory viruses among children with non-severe community-acquired pneumonia: A prospective cohort study. J Clin Virol. 2018; 105:77-83.

5. Kalu SU, Loeffelholz M, Beck E, Patel JA, et al. Persistence of adenovirus nucleic acids in nasopharyngeal secretions: a diagnostic conundrum. Pediatr Infect Dis J. 2010; 29(8):746-50.

6. Bakir J, Juárez MV, Lución MF, Areso MS, et al. Estudio clínico-epidemiológico delas infecciones respiratorias agudas bajas causadas por adenovirus en niños hospitalizados. Diecinueve años de vigilancia epidemiológica activa. Arch Argent Pediatr 2020;118(3):193-201.

7. Lin CY, Hwang D, Chiu NC, Weng LC et al. Increased Detection of Viruses in Children with Respiratory Tract Infection Using PCR. Int J Environ Res Public Health. 2020; 17(2):E564. 